\title{
Organic acid bioavailability from banana and sweet potato using an in vitro digestion and Caco-2 cell model
}

\author{
Houda Sabboh-Jourdan • Fanny Valla • \\ Indah Epriliati · Michael J. Gidley
}

Received: 29 October 2009/Accepted: 14 April 2010/Published online: 29 April 2010

(C) Springer-Verlag 2010

\begin{abstract}
Introduction Organic acids from plant food have been shown to play an important role in the prevention of chronic diseases (osteoporosis, obesity), inherent to western diets, but little is known about their bioavailability in the small intestine, information that needs to be determined in order to quantify likely effects on human health.

Methods An in vitro model of human digestion was carried out, comprising simulated oral, gastric and pancreatic digestion followed by an in vitro model of small intestine absorption using Caco-2 cell monolayers. As models for fruits and vegetables, freeze-dried or raw samples of banana and sweet potato were used.

Results Organic acids have been found to be slowly released from the food matrix during simulated digestion of both banana and sweet potato, either raw or after freezedrying. In the Caco- 2 cell assay, malic and oxalic acids were absorbed more than citric acid. Oxalic and citric acids, but not malic acid, were transported across the cell monolayer. The release and uptake of major organic acids from model fruits and vegetables using established in vitro simulation processes was not quantitative and varied with acid type.
\end{abstract}

H. Sabboh-Jourdan $(\bowtie)$ I. Epriliati · M. J. Gidley

Centre for Nutrition and Food Sciences,

The University of Queensland, Hartley Teakle Building, room S426, St Lucia, QLD 4072, Australia

e-mail: h.sabboh@uq.edu.au

F. Valla

ENSBANA, Université de Bourgogne, 21000 Dijon, France

Present Address:

I. Epriliati

Widya Mandala Catholic University, Surabaya, Indonesia
Conclusion Partial uptake is consistent with a dual nutritional role for organic acids as alkalinising agents (fraction which is taken up) and as modulators of large intestinal function (fraction which is not taken up in the small intestine). Studies of in vivo digestive release and uptake are needed in order to identify the contribution of organic acids to the nutritional value of fruits and vegetables.

Keywords Organic acid - Bioaccessibility ·

Bioavailability · In vitro digestion · Caco-2 cell . Nutrition

\section{Introduction}

Several studies have shown the link between the consumption of fruits and vegetables-rich in biologically active compounds - and the prevention of chronic pathologies such as cancer, obesity and cardiovascular diseases [1-3]. Most of the emphasis in studies of nutritional fruits and vegetables has been on vitamin and other phytochemical components such as carotenoids and anthocyanins [4]. Organic acids are less intensively studied, but are a characteristic feature of fruits and vegetables and one of the components of a diet rich in plant-based foods that have become depleted in Western-style diets [5]. Therefore, the intake and the bioavailability of micronutrients such as organic acids need to be determined to quantify likely effects of food on nutritional status for the population. Previous studies have established the preventive health benefit of organic acid consumption from fruit and vegetables [6-11]. Indeed, these are the main sources of organic acids (chelated with potassium or magnesium) such as malate and citrate, which have been shown to exert 
alkalinizing effects after metabolism, with a potential to prevent low-grade metabolic acidosis inherent to western diet consumption [12-14]. These organic anions are absorbed in the digestive tract and metabolised in various tissues, especially the liver and intestine, and finally produce $\mathrm{CO}_{2}$ and energy [15]. In plant foods, they are partially neutralised, essentially by potassium. This leads to the production of potassium bicarbonate which neutralises fixed acidity produced from protein catabolism [12]. Besides their alkalinising effect, interest in organic acids is increasing due to their potential to modulate short-chain fatty acid (SCFA) production in the large intestine. Previous work on rats has shown that a fibre diet supplemented with potassium citrate changes the caecum SCFA profile by decreasing succinate and increasing butyrate concentrations; compared to a non-supplemented fibre diet [16]. Production of SCFA, especially butyrate, is important for colonic health and may potentially increase mineral absorption, particularly calcium or magnesium, by lowering the colon $\mathrm{pH}$ [17]. Moreover, SCFA might improve mineral absorption by chelating divalent cations which would increase their uptake by intestinal cells [18].

To date, measurements of total concentrations of organic acid nutrients have been reported. To achieve nutritional effects in a specific tissue or organ, all bioactive compounds must be bioavailable, i.e. released from the food and effectively absorbed from the gut into the circulation. Conversely, for effects in the large intestine, bioactive compounds should not be fully absorbed by the end of the small intestine. To assess potential bioavailability, in vitro digestion/Caco-2 cell culture models have been developed in recent years. The model modified from Glahn et al. and from Laurent et al. has been used in the current study [19-22]. In vitro digestion simulates the physiochemical and biochemical conditions encountered in the gastrointestinal tract and is used to estimate the rate and extent of release of bioactive compounds from the food matrix into the intestinal lumen (bioaccessibility) and therefore potentially available for uptake. Originally derived from human colon adenocarcinoma, Caco-2 cells have been studied for their ability to differentiate into enterocytes. The cells can express some features characteristic of mature small intestinal cells, such as a welldefined brush border on the apical cell membrane and tight junctions that only allow molecular passage through cells; as occurs primarily in the digestive tract [23, 24]. This in vitro model is currently the best approach, in term of cost and time, to investigate the bioavailability of food component as a prelude to in vivo studies. Thus, the use of Caco-2 cells is acceptable even though there may exist some physiological differences compared to in vivo conditions, due to the fact that the Caco- 2 cells are of human origin.
The objective of the present study is to determine the in vitro release and absorption of organic acids from plant origin, namely citric, malic and to a lesser extent oxalic acids, which are known to play a key role in western dietinduced metabolic acidosis protection [12]. Thus, to further understand organic acid bioavailability from banana and sweet potato as examples of a fruit and a vegetable, an in vitro model combining human gastric and pancreatic digestion followed by human intestinal absorption (via Caco-2 cells) was investigated in this study.

\section{Materials and methods}

\section{Chemicals}

Citric, malic and oxalic acid were purchased from Sigma (Castle Hill, Australia). Amylase (human salivary), pepsin, bile extract and pancreatin (from porcine stomach mucosa and pancreas) were purchased from Sigma. Dulbecco's modified Eagle medium (DMEM), non-essential amino acid solution (NEAA), L-glutamine solution, antibiotic solution (100 U/L penicillin $\mathrm{G}$ and $100 \mu \mathrm{g} / \mathrm{mL}$ streptomycin), 4-(2-hydroxyethyl)-1-piperazineethanesulfonic acid (HEPES) buffer solution and Foetal bovine serum (FBS) were purchased from Invitrogen (Mulgrave, Australia). Hank's Balance Salt Solution (HBSS), 0.02\% Ethylenediaminetetraacetic acid (EDTA), Dimethyl Sulfoxide (DMSO) and $0.25 \%$ Trypsin/1 mM EDTA solution were purchased from Sigma. HPLC methanol was purchased from LABSCAN (Taren Point, Australia). 1,4-Piperazinediethanesulfonic acid (PIPES) was purchased from Sigma.

\section{Sample preparation}

Fresh mature banana (Musa acuminata) and sweet potato (Ipomoea batatas) samples were purchased from the local supermarket. Sweet potatoes and peeled bananas were cut into small cubes (size: $1 \mathrm{~cm}^{3}$ ) immediately prior to the in vitro digestion experiment. The freeze-dried samples were prepared as follows: fresh bananas and sweet potatoes were cut into small cubes $\left(1 \mathrm{~cm}^{3}\right)$ and placed into petri dishes. After overnight storage at $-20^{\circ} \mathrm{C}$, they were freeze-dried for $80 \mathrm{~h}$ at $-50{ }^{\circ} \mathrm{C}$ and $10.5 \mathrm{mPa}$. Thereafter, the dried pieces were stored in a desiccator or manually ground into powder and stored at $4{ }^{\circ} \mathrm{C}$ until analysis.

In vitro model for human digestion

The protocol was developed by modifying the method of Glahn et al. and Laurent et al. [19-22]. Fresh (4 g) or freeze-dried ( $1 \mathrm{~g}$ ) banana and sweet potato were ground 
with a food chopper from Zyliss ${ }^{\circledR}$ (Oxenford, Australia), applying ten pressures for all samples to simulate mastication. Chopped samples were transferred into $5 \mathrm{~mL}$ of saliva solution $\left(1.3 \mathrm{mmol} / \mathrm{L} \mathrm{CaCl} ; 0.2 \mathrm{mmol} / \mathrm{L} \mathrm{MgSO}_{4}\right.$; $12.8 \mathrm{mmol} / \mathrm{L} \quad \mathrm{KH}_{2} \mathrm{PO}_{4} ; 23.8 \mathrm{mmol} / \mathrm{L} \quad \mathrm{NaHCO}_{3} ; \mathrm{pH}$ 6.9) containing phosphate buffer (diluted 1:5) in a $50-\mathrm{mL}$ falcon tube. $\alpha$-Amylase $(10 \mu \mathrm{l}, 100 \mathrm{U} / \mathrm{L})$ was added and the samples were incubated in a shaking water bath $\left(37^{\circ} \mathrm{C}\right.$, $55 \mathrm{rpm}$ ) for $10 \mathrm{~min}$. To mimic the gastric step, $5 \mathrm{~mL}$ of gastric juice $(130 \mathrm{mmol} / \mathrm{L} \mathrm{NaCl}, 5 \mathrm{mmol} / \mathrm{L} \mathrm{KCl}, 5 \mathrm{mM}$ PIPES) containing $0.5 \mathrm{~mL}$ of pepsin solution $(0.2 \mathrm{~g}$ of pepsin dissolved in $5 \mathrm{~mL} \mathrm{HCl} 0.1 \mathrm{~mol} / \mathrm{L}$ ) was added. The $\mathrm{pH}$ was adjusted to 2 with $1 \mathrm{~N} \mathrm{HCl}$, and the samples were incubated $\left(37^{\circ} \mathrm{C}, 55 \mathrm{rpm}\right)$ for $60 \mathrm{~min}$. After incubation, the $\mathrm{pH}$ was raised to 6.0 by dropwise addition of $1 \mathrm{M}$ $\mathrm{NaHCO}_{3}$ to reproduce the pancreatic medium, and then $2.5 \mathrm{~mL}$ of pancreatic-bile extract $(0.05 \mathrm{~g}$ of pancreatin and $0.3 \mathrm{~g}$ of bile extract dissolved in $25 \mathrm{~mL} \mathrm{NaHCO} 30.1 \mathrm{~mol} /$ L) was added together with $20 \mathrm{~mL}$ of duodenal solution (120 mmol/L NaCl; $5 \mathrm{mmol} / \mathrm{L} \mathrm{KCl})$. The $\mathrm{pH}$ was adjusted to 7.0 with $1 \mathrm{M} \mathrm{NaHCO}_{3}$, and the samples were incubated for $60 \mathrm{~min}\left(37^{\circ} \mathrm{C}, 55 \mathrm{rpm}\right)$.

Aliquots were collected at $10 \mathrm{~min}$ during the mouth step and at 20, 40 and 60 min during gastric and pancreatic digestion. To inactivate the enzymes, all collected digests were put on ice for $10 \mathrm{~min}$. Then, the aliquots were filtered with a Millipore syringe filter of $0.45 \mu \mathrm{m}$, filtered through a $300 \mathrm{mg}$ C18 Sep Pak SPE from and stored at $4{ }^{\circ} \mathrm{C}$ until HPLC analysis or transport experiments were conducted.

\section{Cell culture}

Caco-2 cells were obtained from the American Type Culture Collection (ATCC ${ }^{\circledR}$ HTB- $37^{\mathrm{TM}}$ ) and used in the study between serial passage 24 and 30 . Caco- 2 cells were maintained and expanded in a $25-\mathrm{cm}^{3}$ flask at $37{ }^{\circ} \mathrm{C}$ in an atmosphere of 5\% CO2 and 95\% air at constant humidity. The cells were maintained in Dulbecco's modified Eagle's medium (DMEM) supplemented with 20\% FBS, 1\% L-glutamine, 1\% NEAA for 7 days until reaching $80 \%$ of confluence. Then, the cells were harvested by treatment with $0.25 \%$ Trypsin/1 mM EDTA, washed and resuspended in DMEM with 10\% FBS for 7 days (until $80 \%$ of confluence) into a new $25-\mathrm{cm}^{3}$ flask. For the transport experiment, the cells were seeded at a density of 100,000 cells/insert in a polycarbonate membrane-coated transwell cell culture insert (pore size $0.4 \mu \mathrm{m}$; 24-well plate; $6 \mathrm{~mm}$, Corning Costar) from DKSH (Hallam, Australia). The culture was performed for 21 days postconfluence in DMEM supplemented with $1 \%$ antibiotic solution. The medium was changed every 2 days until day 21.
Transport study of organic acids by Caco- 2 cells

Measurements of the trans epithelial electrical resistance (TEER) were performed using a Millicell-ERS (Millipore) probe equilibrated with the HBSS-25 mM HEPES buffer. Measurements were done before and after each transport bioassay. The TEER is the measurement of the tissue resistance and is a sensitive and convenient method to assess and validate the integrity of the monolayer. The values obtained are determined by the cellular resistance (between luminal and serosal membrane) and the paracellular resistance (tight junctions). These TEER values were corrected by the TEERs of transwell inserts without monolayer containing the HBSS$25 \mathrm{mM}$ HEPES buffer. If the cell monolayer contains nontight junctions, the TEER value is lower $\left(<200 \mathrm{ohm} / \mathrm{cm}^{2}\right)$ than for tight junctions (up to $1,000 \mathrm{ohm} / \mathrm{cm}^{2}$ ) [25].

Samples collected at $60 \mathrm{~min}$ from the simulated pancreatic step were investigated for their potential to be absorbed across the intestinal epithelium using the Caco- 2 cell-based model. Pure citric, oxalic and malic acids at $1 \mathrm{mg} / \mathrm{mL}$ were also investigated. During the bioassay, $200 \mu \mathrm{l}$ of digested samples (previously filtered as mentioned above) or standards were placed in the apical chamber (Fig. 1) of the inserts, and the transport of target species into the basolateral chamber was monitored by analysis of sample aliquots as a function of time. An aliquot of $400 \mu \mathrm{l}$ from the basolateral chamber was collected every $30 \mathrm{~min}$ for $2 \mathrm{~h}$. At the end of the experiment, remaining aliquots from the upper chamber were also collected to compare the concentration of organic acids from the initial time (Fig. 1). Each aliquot collected after trans-cellular transport was analysed by HPLC for organic acid concentrations.

\section{HPLC analysis of organic acids}

Organic acid concentration was measured by HPLC before commencing transport experiments. Standards of pure organic acids (malic, citric, oxalic) were prepared at $1 \mathrm{mg} /$ $\mathrm{mL}$ in ultrapure water (Milli-Q water purification system, Millipore Australia Lty Ptd) as well as a standard mixture (of all acids) for calibration curves at various final concentrations $(1,7.5,15,25,75,100,250,500 \mu \mathrm{g} / \mathrm{mL}$, and $1 \mathrm{mg} / \mathrm{mL}$ ). Samples were also prepared by extraction of ground freeze-dried crops. Powder $(0.5 \mathrm{~g})$ was weighed into a $10-\mathrm{mL}$ plastic vial, and $1 \% \mathrm{H}_{3} \mathrm{PO}_{4}(5 \mathrm{~mL})$ was added. The vials were shaken on an orbital shaker (IKA KS260) for $30 \mathrm{~min}(400 / 450 \mathrm{rpm})$ and centrifuged at $1,900 \mathrm{~g}$ for $10 \mathrm{~min}$ (at $22{ }^{\circ} \mathrm{C}$ ). The supernatant was collected and incubated overnight with $20 \mu \mathrm{l}$ of pectinase at $37{ }^{\circ} \mathrm{C}$ (Optivin ${ }^{\circledR}$ 5XL, Croydon, Australia) to remove any pectin in order to avoid column blockage. Lastly, the samples were filtered with a Millipore syringe filter of $0.45 \mu \mathrm{m}$ from Pall (Melbourne, Australia) and filtered 


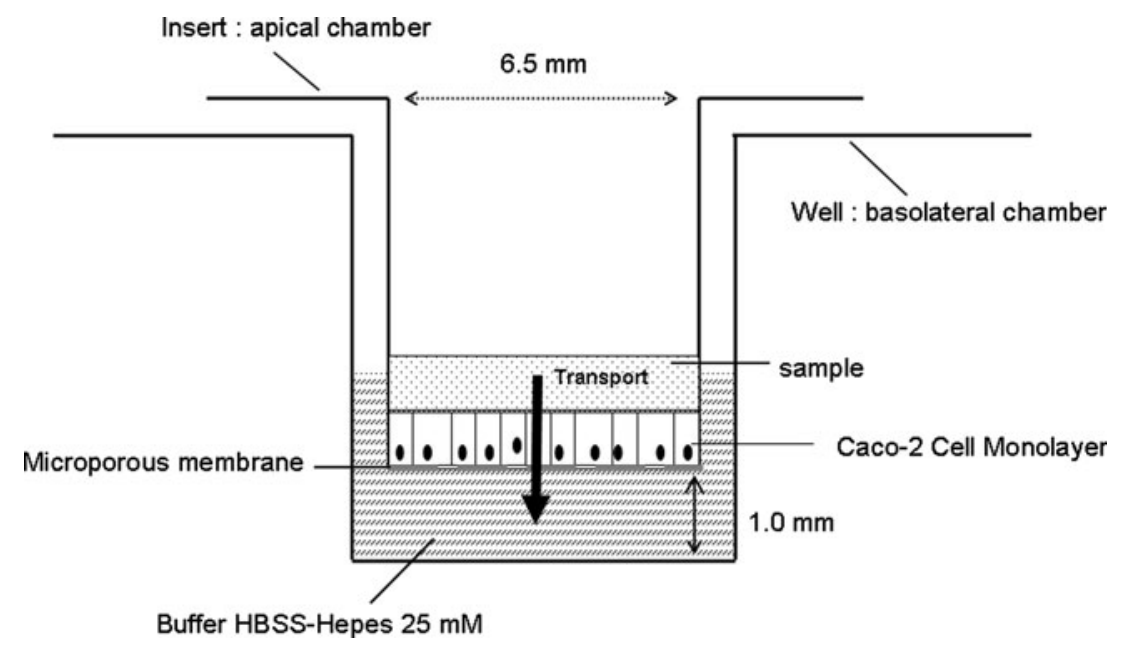

Fig. 1 Schematic diagram of the in vitro Caco-2 cell model for intestinal absorption. During the bioassay, $200 \mu \mathrm{l}$ of digested samples or standards are placed in the apical chamber of the inserts and the transport of target species into the basolateral chamber is monitored by analysis of sample aliquots as a function of time. An aliquot of

through a 300-mg C18 solid phase extraction column (SPE) from Alltech (Baulkham Hills, Australia) as follows: the SPE was conditioned with $1 \mathrm{~mL}$ of $100 \%$ methanol and then rinsed with $5 \mathrm{~mL}$ of pure water to remove any residual methanol. A volume of $3 \mathrm{~mL}$ of extract was passed through the SPE and $1 \mathrm{~mL}$ was collected for analysis.

The instrumental setup used was an HPLC Shimadzu instrument (Tokyo, Japan) composed of a SIL-10AD auto injector, a LC-10AT pump, a DGU-14A degasser, a CTO10AS column oven, a SPD-10AS UV Vis detector and a SCL-10A system controller. Separation of the organic acids was achieved using an isocratic mobile phase composed of $25 \mathrm{mM}$ potassium phosphate at $\mathrm{pH}$ 2.5. The column used was an Alltech Prevail OA (GRACE Davison Discovery Sciences, Victoria, Australia), $5 \mu \mathrm{m}, 250 \times 4.6 \mathrm{~mm}$, and the mobile phase was set at a flow rate of $1 \mathrm{~mL} / \mathrm{min}$. The UV detection was at $210 \mathrm{~nm}$ and the column temperature at $25{ }^{\circ} \mathrm{C}$. The injection volume was $20 \mu \mathrm{l}$.

\section{Statistical analysis}

Values are given as the means \pm SEM, and significance of differences $(P<0.05)$ between mean values was determined, by analysis of variance (ANOVA) using a general linear model (GLM), with Minitab 15 Software.

\section{Results}

Chromatography validation

Validation of the method included assessment of accuracy, linearity, precision and limits of detection. The results are
$400 \mu \mathrm{l}$ from the basolateral chamber is collected every $30 \mathrm{~min}$ for $2 \mathrm{~h}$, and at the end of the experiment, remaining aliquots from the upper chamber are also collected to compare the concentration of organic acids from the initial time. HBSS, Hank's balance salt solution

summarised in Table 1. The accuracy of the method was tested with different concentrations of the standards. Recoveries of citric, oxalic and malic acids from the Prevail organic acid column were higher than $86 \%$. The calibration curves were prepared using 8 concentrations within the range $7.5-1,000 \mu \mathrm{g} / \mathrm{mL}$. The linearity of response for the standards was high as shown by the regression coefficients $\left(\mathrm{r}^{2}\right)$ which were greater than 0.998 . The intraday precision was tested with 6 repeated samples of each organic acid. The relative standard deviations (RSD) were less than $5 \%$. The limits of detection $(n=6)$ at a signal-to-noise ratio of 3 were 10.7, 8.9 and $0.4 \mu \mathrm{g} / \mathrm{mL}$ for citric, malic and oxalic acids, respectively.

In vitro digestion and release of organic acids

Figure 2 shows the HPLC chromatograms of total organic acids and their release after simulated gastric and pancreatic digestion, from banana (a) and sweet potato (b). It is interesting to observe that chromatograms of total organic acids before and after digestion have different patterns.

Quantification of the results from in vitro gastric and pancreatic banana digestion is shown in Fig. 3. The percentage of release of oxalic acid (Fig. 3a) and citric acid (Fig. 3b) is higher from fresh fruit than from processed ones, but the maximum amount released after combined gastric and intestinal simulated digestion was 50\%. Each step of digestion (mouth, gastric and pancreatic) caused a significant $(P<0.05)$ release of organic acids, especially of oxalic acid, from the food matrix compared to the previous step. The release was also more relevant during the pancreatic/intestinal step with a maximum release after $20 \mathrm{~min}$. 
Table 1 Chromatography validation including calibration curve parameters, accuracy, precision and limits of detection of the organic acid standards

\begin{tabular}{|c|c|c|c|c|c|c|}
\hline & \multicolumn{3}{|c|}{$Y=a X+b^{\mathrm{a}}$} & \multirow[t]{2}{*}{$\%$ Recovery $^{\mathrm{b}}$} & \multirow[t]{2}{*}{ Precision $(\mathrm{RSD})^{\mathrm{d}}$} & \multirow[t]{2}{*}{$\operatorname{LOD}^{c}(\mu \mathrm{g} / \mathrm{mL})$} \\
\hline & $a$ & $b$ & $r^{2}$ & & & \\
\hline Citric acid & 1.5 & 27.0 & 0.9998 & 86.6 & 0.8 & $10.7 \pm 2.1$ \\
\hline Malic acid & 1.1 & 1.2 & 0.9999 & 104.8 & 4.7 & $8.9 \pm 1.6$ \\
\hline Oxalic acid & 1.7 & 11.8 & 0.9999 & 101.2 & 2.5 & $0.4 \pm 0.1$ \\
\hline
\end{tabular}

${ }^{a}$ In the calibration formula, $a$ is the slope of the regression line and $b$ is the intercept of the regression line

b The percentage of recovery has been calculated from the Prevail organic acid column

c The corresponding concentrations to the LOD for citric, malic and oxalic acids are 15,15 and $1 \mu \mathrm{g} / \mathrm{mL}$, respectively. Values are the means $\pm \mathrm{SD}(n=6)$

${ }^{\mathrm{d}} \mathrm{RSD}$, relative standard deviation
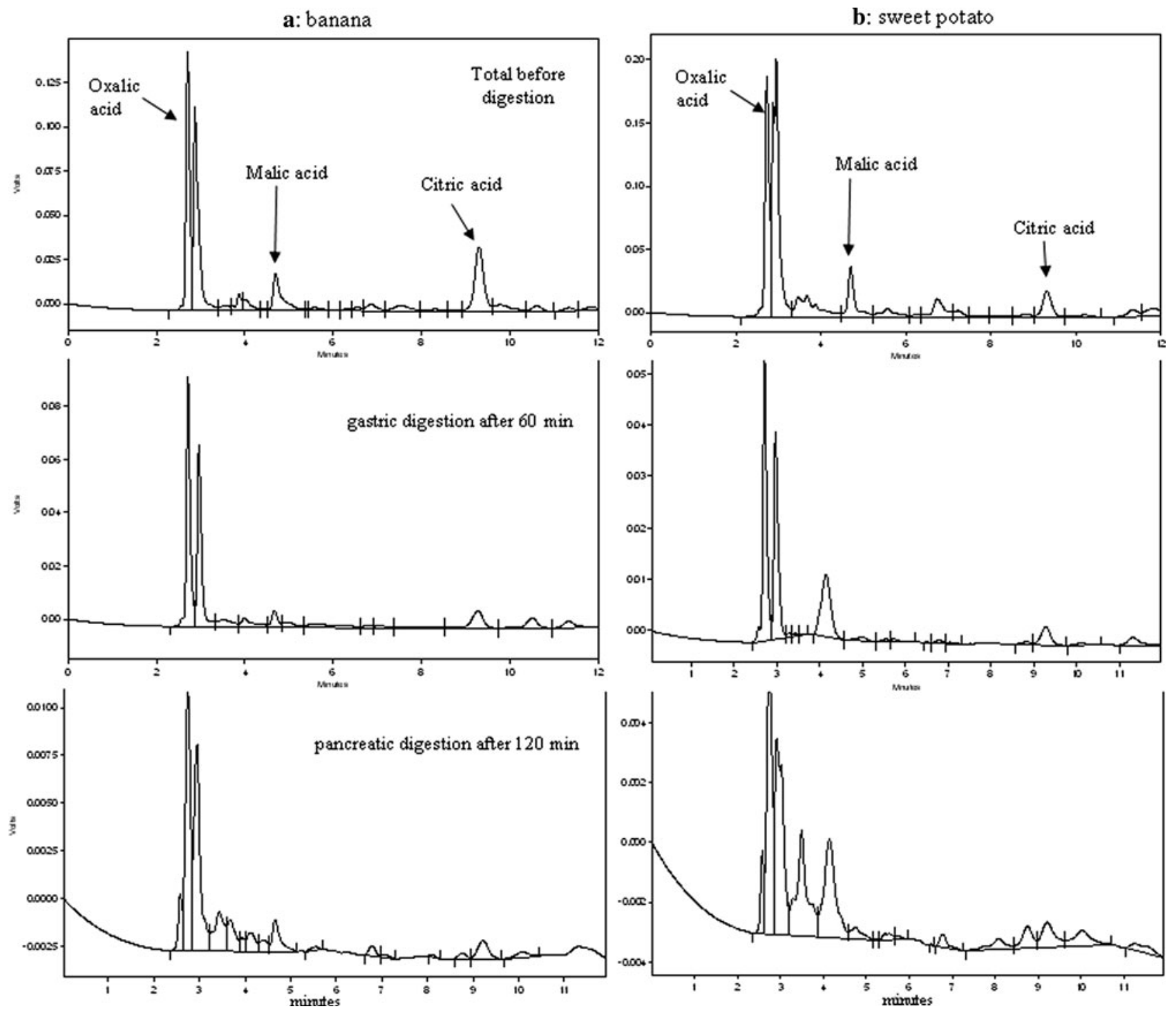

Fig. 2 HPLC chromatograms of total organic acid concentration as well as the chromatograms of organic acid released after simulated gastric and pancreatic digestion, from banana $(\mathbf{a})$ or sweet potato $(\mathbf{b})$ 


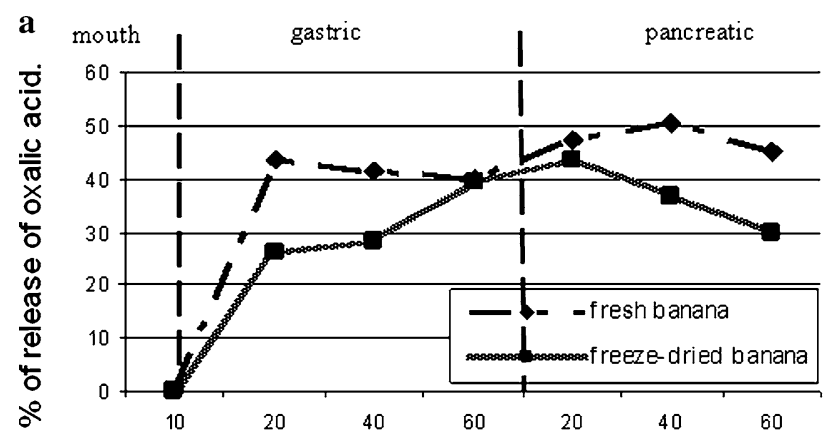

b
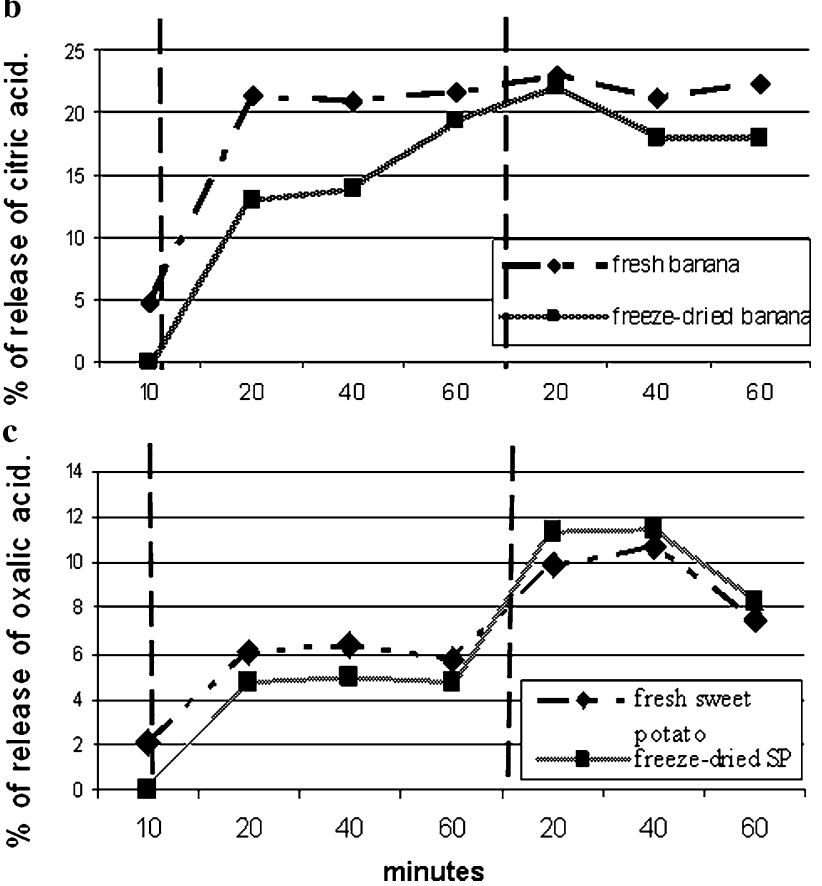

Fig. 3 Kinetic of release of oxalic acid (a) and citric acids (b) during in vitro mouth-, gastric- and pancreatic-simulated digestion of fresh or processed banana. c Kinetic of release of oxalic acid during in vitro digestion of fresh or processed sweet potato. Values are the means $\pm \operatorname{SEM}(n=3)$ determined by HPLC, expressed as a percentage of the initial concentration in dry (for freeze-dried) or fresh crops

A similar trend was observed for the sweet potato samples, with an increased release during the pancreatic step of oxalic acid: 10.7 and $11.5 \%$ from fresh and freezedried, respectively (Fig. 3c). However, the percentage amount of oxalic acid released from sweet potato samples was much less than from banana (ca $10 \%$ vs. ca $40 \%$ ).

Transport study of organic acids by Caco- 2 cells

In our study, the cell monolayer TEER values were ranging between 500 and $800 \mathrm{ohm} / \mathrm{cm}^{2}$ (data not shown). The pure acid standards were tested during the transport bioassay. A significant decrease of malic acid concentration of ca $65 \%$ $(P<0.05)$ was observed in the upper chamber after 2 -h
Table 2 Pure organic acid concentrations in the inserts (apical chamber) before $(t 0 \mathrm{~min})$ and after $(t 120 \mathrm{~min})$ the in vitro Caco-2 cell transport bioassay

\begin{tabular}{llll}
\hline & \multicolumn{2}{l}{$\begin{array}{l}\text { Organic acid concentration } \\
(\mu \mathrm{g} / \mathrm{mL})\end{array}$} & \multirow{2}{*}{$\%$ of disappearance } \\
\cline { 2 - 3 } & $t 0 \mathrm{~min}$ & $t 120 \mathrm{~min}$ & \\
\hline Citric acid & $475.9 \pm 1.1$ & $344.5 \pm 36.6$ & 27.6 \\
Malic acid & $761.1 \pm 4.0$ & $265.3 \pm 18.6^{*}$ & 65.1 \\
Oxalic acid & $346.9 \pm 2.3$ & $122.6 \pm 29.3^{*}$ & 64.7 \\
\hline
\end{tabular}

Values are the means $\pm \operatorname{SEM}(n=3)$ expressed in $\mu \mathrm{g} / \mathrm{mL}$

* A significant difference $(P<0.05)$ compared to the initial state $(t$ $0 \mathrm{~min}$ )

incubation (Table 2). In contrast to malic acid, a much lower (statistically insignificant) decrease in citric acid (around 28\%) from the upper chamber concentration was observed (Table 2).

A significant disappearance of oxalic acid (similar to malic acid) of $65 \%$ was observed from the upper chamber (Table 2). It should be noted that oxalic acid was the only standard acid found in the bottom chamber with a percentage of recovery quite high (around 70\%).

The in vitro transport of organic acids from banana and sweet potato is illustrated in Fig. 4a and b, respectively. We can observe from the HPLC chromatograms that the patterns are different before $(t 0 \mathrm{~min})$ and after $(t 120 \mathrm{~min})$ the bioassay in the apical chamber, showing that some components have disappeared from the apical side of the monolayer. The chromatogram from the basolateral chamber shows that oxalic acid peak was detected after 120 min from both banana and sweet potato digests in contrast to citric and malic acid peaks which were not detected in the basolateral chamber.

The oxalic acid flux via the cell monolayer for samples released from fresh or freeze-dried banana digests is shown in Fig. 5. The values obtained for oxalic acid flux were between 10 and $30 \mu \mathrm{g} / \mathrm{min} / \mathrm{cm}^{2}$ with a maximum flux at 30 and $60 \mathrm{~min}$ for fresh and freeze-dried banana, respectively. By expressing the passage rate $(\mu \mathrm{g} / \mathrm{min})$ as a function of cell monolayer area $\left(\mathrm{cm}^{2}\right)$, it is possible to extrapolate to potential in vivo uptake rates by choosing an appropriate value for intestinal epithelial cell areas available for uptake in vivo.

\section{Discussion}

In vitro digestion and release of organic acids

The different patterns observed from HPLC chromatograms of organic acid digestion release (Fig. 2) seem to indicate that individual organic acids are released 

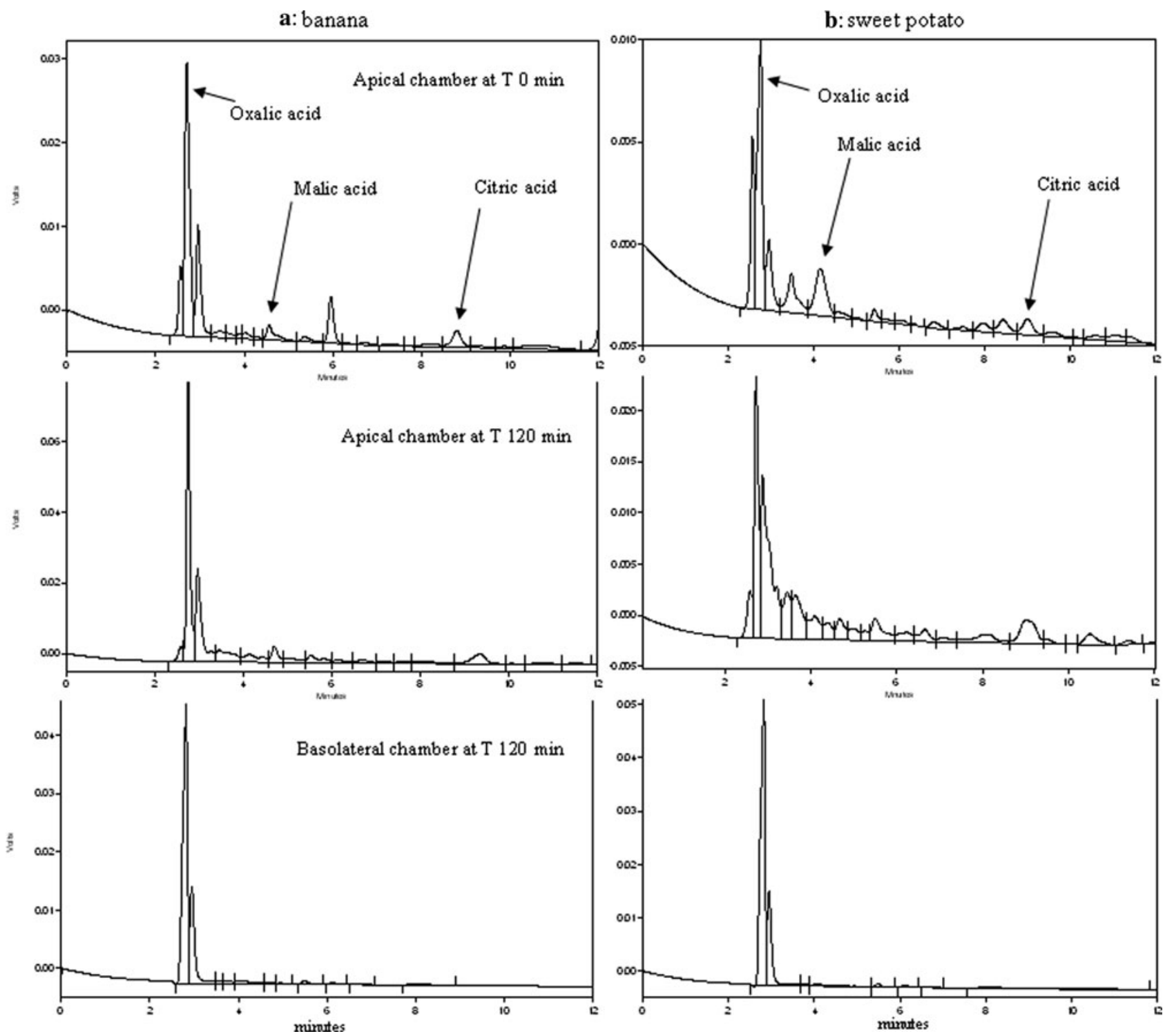

Fig. 4 HPLC chromatograms of organic acid concentrations in the apical chamber before $(t 0 \mathrm{~min})$ and after $(t 120 \mathrm{~min})$ the cell monolayer transport bioassay as well as the organic acid concentrations in the basolateral chamber at $t 120 \mathrm{~min}$; from banana (a) and sweet potato (b)

differentially from the cell matrix after gastric and pancreatic digestion. Quantification of the results from in vitro gastric and pancreatic banana digestion (Fig. 3) confirms this observation and shows that acids were released gradually and incompletely. As they are such small and hydrophilic compounds, it is perhaps surprising that the organic acids released were globally less than $50 \%$ of the total content. This is most likely due to slow passage of organic acids across cell walls during the in vitro digestion process and the lack of cell wall-degrading enzymes in the upper digestive tract, thus limiting the amount of organic acids released. If this mechanism is correct, then release of organic acids would be predicted to occur mostly in the large intestine where microbial enzymes would be expected to breakdown cell walls and enhance release of organic acids from the food matrix.

The difference of amount of acids released from sweet potato suggests that plant structure has an influence on the rate and extent of release. The more robust cellular structure of sweet potato is the most likely reason for the different rates and extent of release of, for e.g., oxalic acid from sweet potato and banana. The difference between the two crops in terms of release behaviour was greater than the difference between fresh and dried forms of the same crop (Fig. 3).

These preliminary results are very interesting as to the best of our knowledge; the release of organic acid from plant-based foods during digestion has not previously been 


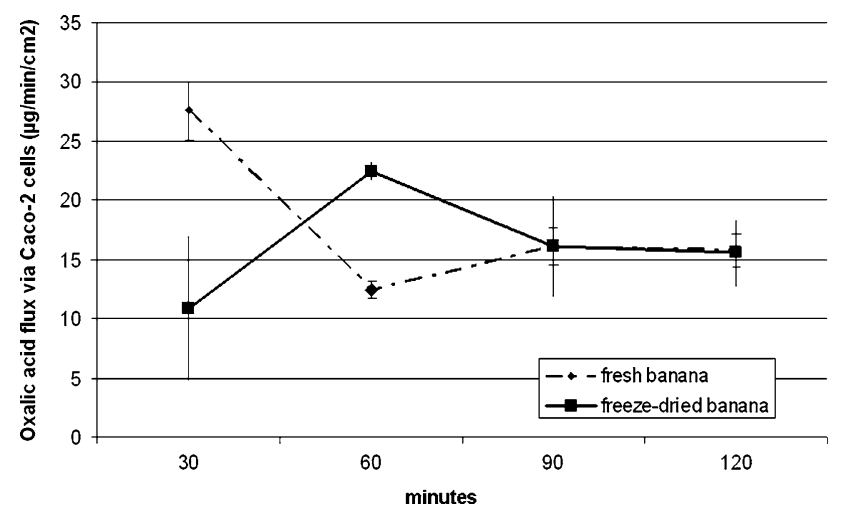

Fig. 5 Oxalic acid flux of pancreatic digests through the Caco-2 cell monolayer. Values are the means $\pm \operatorname{SEM}(n=3)$ expressed in $\mu \mathrm{g} /$ $\mathrm{min} / \mathrm{cm}^{2}$. By expressing the passage rate $(\mu \mathrm{g} / \mathrm{min})$ as a function of cell monolayer area $\left(\mathrm{cm}^{2}\right)$, it is possible to extrapolate to potential in vivo uptake rates

studied in vitro. Many other nutrients such as carotenoids [26], iron [27, 28], calcium [29, 30] or polyphenols [27, 31] have been studied for their intestinal bioavailability using a model of in vitro digestion alone or combining in vitro digestion/Caco-2 cell. However, in most of these studies, the digests were directly used for intestinal absorption without focusing on the nutrient release as a function of time per se. A few studies have investigated digestion nutrient bioavailability. Among them, one study [32] evaluated the bioavailability of carotenoids and tocopherols present in broccoli using both in vitro and in vivo approaches. During their in vitro digestion, the authors also collected samples from each step of the digestion for nutrient analysis. They discovered that more than $75 \%$ of lutein, $\beta$-carotene, retinol and $\alpha$-tocopherol remained within the food matrix at the duodenal phase.

From our study, HPLC analysis of processed sweet potato digests, compared to fresh samples, indicated that a smaller part of the total acids was available after the in vitro digestion (data not shown). Although process techniques, such as freeze-drying, could disrupt food membrane microstructure [33] favouring release, they could also cause compaction of cell wall matrices making release less favourable. The very low release extent of acids observed may also be partly due to the limited incubation time of the pancreatic/intestinal step (120 min), which may be longer under in vivo conditions.

Transport study of organic acids by Caco- 2 cells

It is established from the literature that an acceptable TEER value for Caco- 2 cell monolayers should be from 200 to $1,000 \mathrm{ohm} / \mathrm{cm}^{2}$ [34]. Others studies have considered that acceptable TEER values for bioassays were $>400 \mathrm{ohm} / \mathrm{cm}^{2}$ $[25,35]$. Lower values indicate that tight junctions between cells are not developed enough or are damaged such that some small molecules could pass via a paracellular route to the basolateral chamber. Our results obtained between 500 and $800 \mathrm{ohm} / \mathrm{cm}^{2}$ seem to indicate good integrity of the monolayer during the bioassay experiment.

The results obtained for standard malic acid are very interesting (Table 2). Indeed, this indicates that malic acid has been either taken up by the monolayer or transported through. Steinert [36] reported that the absorption of a compound from the luminal to the serosal compartment can be expressed by the decrease of the concentration in the upper chamber. In vivo, it is well established now that the intestinal monolayer is able to absorb and to transport nutrients from the intestinal lumen to the blood capillary [37]. After $1 \mathrm{~h}$ of bioassay, several components were detected in the bottom of the insert as shown by HPLC analysis (data not shown). Our results showed that the retention times obtained did not match with any of the tested standards in the study; thus malic acid might have been metabolised in the cell monolayer yielding compounds that were detected in the bottom chamber. Indeed, malic acid is known to be involved in the citric acid cycle and to take part in the production of tricarboxylic cycle intermediates such as oxaloacetate. Alternatively, a portion of the absorbed malic acid could still be inside the cells without being metabolised. Concerning citric acid, there is little information about its intestinal transport in mammals. Some studies have shown an intestinal transepithelial transport of citrate in humans [38, 39], in calves [40] or in rat small intestine using sacs of everted intestine [15]. The citrate is transported in the mono-protonated form citrate ${ }^{2-}$ [41]. Oxalic acid from the diet is less absorbed and poorly metabolised in the tissues compared to malate or citrate, and the absorbed part is essentially channelled towards kidney excretion [12]. The high recovery of oxalic acid in the basolateral chamber suggests that metabolism within the cells was minor.

Steinert [36] found that the highest transport efficiencies of anthocyanins across Caco- 2 cells were reached after $1 \mathrm{~h}$, followed by a notable drop. Our study (Table 2; Fig. 4) showed that neither citrate nor malate could be detected in the bottom chamber in contrast to oxalate, which may suggest that oxalate was less metabolisable than the other organic acids. This result is interesting since there is no experimental evidence so far for the transepithelial fluxes of organic acids across Caco-2 cells (Fig. 5). A previous study could not measure any transepithelial flux of citrate (or succinate) across Caco-2 cells, indicating that the substrate was possibly metabolised or that the concentrations were too low to be measured [42]. In vivo, the intestinal basolateral membrane may contain $\mathrm{Na}^{+}$-independent pathways for transport of citrate and tricarballylate, a non-metabolizable tricarboxylate. The basolateral 
transporter may be an anion exchanger [15], but to the best of our knowledge, no citrate transporter has been shown in the basolateral membrane in the Caco- 2 cells, which would explain why no citrate was found in the basolateral chamber in our study.

In conclusion, although release rates and extents may be enhanced by cooking processes, results obtained for soft (raw) banana tissue suggest that limited organic acid release may be a general feature for solid fruits and vegetables. Simulated intestinal transport of organic acids from digests has shown the possible metabolism of malate and citrate within Caco- 2 cells, consistent with the in vivo hypothesis of citrate and malate metabolism within enterocytes.

It is surprising to observe such a difference of behaviour in both digestion release and cell transport between the different organic acids. The studied acids are all polycarboxylates, and not very different in terms of structure, but they were not released or absorbed at the same rate. Hypotheses such as a different affinity of organic acids for minerals (potassium and calcium) or other compounds of the cell wall matrix (e.g., pectin) could explain the diverse behaviours observed. Minerals such as potassium, calcium and magnesium are well known to be chelated to the organic acids in plant food and therefore play an important role on the alkalinising impact of fruits and vegetables and thus their protective impact against chronic diseases [43]. The difference in release behaviour could also be explained by the in vitro conditions, namely temperature or $\mathrm{pH}$ that affects the matrix and its components (such as pectin or hemicelluloses) which may then affect the organic acid release pattern. Moreover, previous study from Epriliati et al. (2009) also found differences in behaviour between organic acids from fresh or processed mango and papaya during in vitro transport. The authors found some citric and malic acids in the basolateral chamber, which is not the case in the present study. This could be explained by the fact that the cells may metabolically consume different organic acids depending on other components released from the relevant fruit or vegetable [35].

One consequence of incomplete release of organic acids from solid fruits and vegetables under gastric and small intestinal conditions is that a significant fraction will survive to the large intestine. It is possible that this could have positive effects on fermentation processes [8] and that organic acids could have dual nutritional benefits of (a) combating metabolic acidosis (fraction taken up from the small intestine) and (b) modulation of large intestinal microbial metabolism (fraction not taken up from the small intestine). As the plant tissue structure is likely to be the origin of the incomplete release of organic acids from fruits and vegetables, only solid forms of these foods would be expected to provide organic acids for large intestinal fermentation.

Acknowledgments The authors would like to thank Lesleigh Force and Graham Kerven for their advice and helpful technical support. This work was supported by a University of Queensland Postdoctoral Fellowship awarded to HS and an AusAid Scholarship awarded to IE. The authors acknowledge that there is no conflict of interest. The contribution of the authors to the study is as follows: M.J.G. was the chief investigator and secured the funding, H.S.J. was the project leader and writer of the manuscript, F.V. contributed to the set up of the in vitro digestion and Caco-2 cell model for micronutrients and micronutrient analysis and I.E. provided topic expertise on the in vitro digestion and Caco-2 cell model.

\section{References}

1. Greenwald P, Clifford CK, Milner JA (2001) Diet and cancer prevention. Eur J Cancer 37:948-965

2. Hooper L, Bartlett C, Davey Smith G, Ebrahim S (2004) Advice to reduce dietary salt for prevention of cardiovascular disease. Cochrane Database Syst Rev. doi:10.1002/14651858.CD003656. pub2

3. Trichopoulou A, Psaltopoulou T, Orfanos P, Trichopoulos D (2006) Diet and physical activity in relation to overall mortality amongst adult diabetics in a general population cohort. J Intern Med 259:583-591

4. Key TJ, Appleby PN, Allen NE, Travis RC, Roddam AW, Jenab M, Egevad L, Tjonneland A, Johnsen NF, Overvad K, Linseisen J et al (2007) Plasma carotenoids, retinol, and tocopherols and the risk of prostate cancer in the European prospective investigation into cancer and nutrition study. Am J Clin Nutr 86:672-681

5. Cordain L, Eaton SB, Sebastian A, Mann N, Lindeberg S, Watkins BA, O'Keefe JH, Brand-Miller J (2005) Origins and evolution of the Western diet: health implications for the 21st century. Am J Clin Nutr 81:341-354

6. Barcelo P, Wuhl O, Servitge E, Rousaud A, Pak CY (1993) Randomized double-blind study of potassium citrate in idiopathic hypocitraturic calcium nephrolithiasis. J Urol 150:1761-1764

7. Marangella M, Di Stefano M, Casalis S, Berutti S, D'Amelio P, Isaia GC (2004) Effects of potassium citrate supplementation on bone metabolism. Calcif Tissue Int 74:330-335

8. Sakhaee K, Alpern R, Jacobson HR, Pak CY (1991) Contrasting effects of various potassium salts on renal citrate excretion. J Clin Endocrinol Metab 72:396-400

9. Sakhaee K, Maalouf NM, Abrams SA, Pak CY (2005) Effects of potassium alkali and calcium supplementation on bone turnover in postmenopausal women. J Clin Endocrinol Metab 90:3528-3533

10. Sellmeyer DE, Schloetter M, Sebastian A (2002) Potassium citrate prevents increased urine calcium excretion and bone resorption induced by a high sodium chloride diet. J Clin Endocrinol Metab 87:2008-2012

11. Tekin A, Tekgul S, Atsu N, Bakkaloglu M, Kendi S (2002) Oral potassium citrate treatment for idiopathic hypocitruria in children with calcium urolithiasis. J Urol 168:2572-2574

12. Demigne C, Sabboh H, Puel C, Coxam V (2004) Organic anions potassium in nutrition and metabolism. Nutr Res Rev 17:249-258

13. Frassetto LA, Todd KM, Morris RCJ, Sebastian A (1998) Estimation of net endogenous noncarbonic acid production in humans from diet potassium and protein contents. Am J Clin Nutr 68:576-583

14. Sabboh H, Horcajada MN, Coxam V, Tressol JC, Besson C, Remesy C, Demigne C (2005) Effect of potassium salts in rats 
adapted to an acidogenic high-sulfur amino acid diet. Br J Nutr 94:192-197

15. Wolffram S, Unternahrer R, Grenacher B, Scharrer E (1994) Transport of citrate across the brush border and basolateral membrane of rat small intestine. Comp Biochem Physiol Physiol 109:39-52

16. Sabboh H, Besson C, Tressol JC, Coudray C, Horcajada MN, Coxam V, Remesy C, Demigne C (2006) Organic potassium salts or fibers effects on mineral balance and digestive fermentations in rats adapted to an acidogenic diet. Eur J Nutr 45:342-348

17. Scharrer E, Lutz T (1990) Effects of short chain fatty acids and K on absorption of $\mathrm{Mg}$ and other cations by the colon and caecum. Z Ernahrungswiss 29:162-168

18. Trinidad TP, Wolever TMS, Thompson LU (1999) Effects of calcium concentration, acetate, and propionate on calcium absorption in the human distal colon. J Nutr 15:529-533

19. Glahn RP, Chen SQ, Welch RM, Gregorio GB (2002) Comparison of iron bioavailability from 15 rice genotypes: studies using an in vitro digestion/caco-2 cell culture model. J Agric Food Chem 50:3586-3591

20. Glahn RP, Lee OA, Yeung A, Goldman MI, Miller DD (1998) Caco-2 cell ferritin formation predicts nonradiolabeled food iron availability in an in vitro digestion Caco- 2 cell culture model. J Nutr 128:1555-1561

21. Glahn RP, Wien EM, VanCampen DR, Miller DD (1996) Caco-2 cell iron uptake from meat and casein digests parallels in vivo studies: use of a novel in vitro method for rapid estimation of iron bioavailability. J Nutr 126:332-339

22. Laurent C, Besancon P, Auger C, Rouanet JM, Caporiccio B (2004) Grape seed extract affects proliferation and differentiation of human intestinal caco-2 cells. J Agric Food Chem 52:33013308

23. Blais A, Aymard P, Lacour B (1997) Paracellular calcium transport across Caco-2 and HT29 cell monolayers. Pflugers Archiv 434:300-305

24. Sambuy Y, Angelis I, Ranaldi G, Scarino ML, Stammati A, Zucco F (2005) The Caco-2 cell line as a model of the intestinal barrier: influence of cell and culture-related factors on Caco-2 cell functional characteristics. Cell Biol Toxicol 21:1-26

25. Blanchfield JT, Dutton JL, Hogg RC, Gallagher OP, Craik DJ, Jones A, Adams DJ, Lewis RJ, Alewood PF, Toth I (2003) Synthesis, structure elucidation, in vitro biological activity, toxicity, and Caco-2 cell permeability of lipophilic analogues of alpha-conotoxin MII. J Med Chem 46:1266-1272

26. Liu CS, Glahn RP, Liu RH (2004) Assessment of carotenoid bioavailability of whole foods using a Caco- 2 cell culture model coupled with an in vitro digestion. J Agric Food Chem 52:43304337

27. Au AP, Reddy MB (2000) Caco-2 cells can be used to assess human iron bioavailability from a semipurified meal. J Nutr 130:1329-1334

28. Camara F, Barbera R, Amaro MA, Farre R (2007) Calcium, iron, zinc and copper transport and uptake by Caco-2 cells in school meals: influence of protein and mineral interactions. Food Chem 100:1085-1092

29. Perales S, Barbera R, Lagarda MJ, Farre R (2005) Bioavailability of calcium from milk-based formulas and fruit juices containing milk and cereals estimated by in vitro methods (solubility, dialyzability, and uptake and transport by caco- 2 cells). J Agric Food Chem 53:3721-3726

30. Viadel B, Barbera R, Farre R (2006) Uptake and retention of calcium, iron, and zinc from raw legumes and the effect of cooking on lentils in Caco-2 cells. Nutr Res 26:591-596

31. Green RJ, Murphy AS, Schulz B, Watkins BA, Ferruzzi MG (2007) Common tea formulations modulate in vitro digestive recovery of green tea catechins. Mol Nutr Food Res 51:1152-1162

32. Granado F, Olmedilla B, Herrero C, Perez-Sacristan B, Blanco I, Blazquez S (2006) Bioavailability of carotenoids and tocopherols from broccoli: in vivo and in vitro assessment. Exp Biol Med (Maywood) 231:1733-1738

33. Uwins PJR, Murray M, Gould RJ (1993) Effects of 4 different processing techniques on the microstructure of potatoes-comparison with fresh samples in the Esem. Microsc Res Tech $25: 412-418$

34. Withington L (2002) High-throughput epithelial cell systems for screening drug intestinal permeability. In: Lehr C-M (ed) Cell culture models of biological barriers-in vitro test systems for drugs absorption and delivery. Taylor \& Francis, London, pp 95111

35. Epriliati I, D’Arcy B, Gidley MJ (2009) Nutriomic analysis of fresh and processed fruit products. 2. During in vitro simultaneous molecular passages using caco-2 cell monolayers. J Agric Food Chem 57:3377-3388

36. Steinert RE (2007) Transport of black currant anthocyanins across monolayers of human intestinal Caco- 2 cells mounted in using-type chambers. In: Biological \& pharmaceutical faculty. Friedrich-Schiller University, Jena

37. McColl I, Sladen GE (1975) Intestinal absorption in man. Academic Press, London

38. Pajor AM (1999) Citrate transport by the kidney and the intestine. Semin Nephrol 19:195-200

39. Sakhaee K, Alpern R, Poindexter J, Pak CYC (1992) Citraturic response to oral citric-acid load. J Urol 147:975-976

40. Wolffram S, Bisang B, Grenacher B, Scharrer E (1990) Transport of tricarboxylic and dicarboxylic acids across the intestinal brushborder membrane of calves. J Nutr 120:767-774

41. Wright SH, Kippen I, Wright EM (1982) Effect of pH on the transport of Krebs cycle intermediates in renal brush-border membranes. Biochim Biophys Acta 684:287-290

42. Weerachayaphorn J, Pajor AM (2008) Identification of transport pathways for citric acid cycle intermediates in the human colon carcinoma cell line, Caco-2. Biochim Biophys Acta 1778:10511059

43. Demigne C, Sabboh H, Remesy C, Meneton P (2004) Protective effects of high dietary potassium: nutritional and metabolic aspects. J Nutr 134:2903-2906 